\title{
THE ECONOMIC CONSEQUENCES OF SUPPORTING ORGANIC FARMS BY PUBLIC FUNDS: CASE OF POLAND
}

\author{
Zofia KOLOSZKO-CHOMENTOWSKA \\ Faculty of Management, Bialystok University of Technology, \\ Wiejska Street 45A, 15-351 Bialystok, Poland
}

Received 22 October 2012; accepted 12 April 2014

\begin{abstract}
Research proves that the financial support of agriculture is necessary in order to achieve sustainable economic development with other sectors of the economy. The aim of this paper is to assess the economic results of organic farms which benefit from public funds. The research issue was worked out on the basis of the data from organic farms in Podlasie voievodeship in the years 2008-2012. For the purposes of the analysis, farms were divided into area groups: group I - farms with an area up to 20 ha and group II - farms with an area above 20 ha. The following indicators are calculated: family farm income, current ratio, re-investment fixed assets rate, return on equity $(R O E)$. Higher influence of public funds was observed in farms with an area of 20 ha of utilised agricultural area. The income per working person was almost double in larger farms while equity profitability was four times higher than in smaller farms. Only larger farms had the ability to reproduce their used assets. The organic farms realise many important functions in maintenance of the natural environment and so support of these farms by public funds is justified.
\end{abstract}

Keywords: agriculture, sustainable development, organic farms, public support.

JEL Classification: Q12, Q57.

\section{Introduction}

Sustainable development - identified with eco-development - is understood as a course of economic development that does not significantly and irreversibly violate the human environment, reconciling the laws of nature and the economy (Kozłowski 1996). The concept of such development is in accordance with the view that quality of life is dependent on social, economic, and ecological factors (Barbier 1987). The maintenance of biological diversity and resistance and integrity of natural systems enter into ecological determinants. Aims pertaining to economic areas of stability include: achievement of an income which provides 
farmers with a fair living standard, meeting of the nutritional needs of society, and care for the cultural heritage in the countryside areas, but also include limiting inequality and providing stable economic growth (Łojewski et al. 2000; Lawn 2003; Liu 2010) while social aims stress access to socially desired benefits (Daly, Cobb 1989; Bartolini et al. 2005; Wysokińska 2009).

Implementation of a program for balanced development is especially significant in agriculture in order to make decisions about production (Kurlavicius 2009). As a result of the industrial development of agriculture in highly developed countries, the natural character of rural areas has been lost. The development of civilisation, changing consumer needs, and growing technological capabilities have led to the industrialization of methods of agricultural production. The natural environment of rural areas has been burdened with all of the negative effects resulting from this path of development. Therefore, there is a need for integration of actions aiming towards solutions for preserving the value of the natural environment while simultaneously allowing for the realisation of economic goals. Sustainable agricultural development gives such possibilities in aiming to tie economic development with the protection of natural resources and the balance of the global ecosystem. An integral part of constant and sustainable development of agriculture is organic agriculture. According to G. Benckiser (2010), about $60 \%$ of the world's ecosystems are not utilised in accordance with the principles of sustainable development. Lichtfouse et al. (2009) postulate co-operation of a wide group of scientists of various disciplines for the elaboration of new environment-friendly agricultural practices.

Management under the principles of sustainable development requires knowledge of the interdependence between economic activity of man and the environment. This also refers to agriculture toward which the social expectations are very high. Not only are adequate quantities of high quality agricultural products expected but also the preservation of environmental values is necessary. Implementation of sustainable development of agriculture and rural areas promotes achieving these goals. It constitutes an integral part of the overall idea of sustainable development of the country, the knowledge-based development. The idea can be implemented only by well educated people, who understand the complexity of the relation: people-work-environment.

Sustainable development of rural areas has become an important task for Common Agricultural Policy. This is reflected in supporting the sustainable development of rural areas with public funds. These issues are regulated by Council regulation (EC) No. 1698/2005 (Council of the European Union 2005). According to the regulation rural development policy should be accompanied by income promotion policy, environment condition improvement and higher quality of life in rural areas. Among the many instruments of this policy, is a program based on the realisation of specific actions within the framework of agri-environmental packages. In Poland, it is an element of the Plan for Development of Rural Areas for the years 2007-2013 and it includes 9 packages with different agri-environmental variants, the selection of which creates the obligation to realise detailed tasks. One of these packages is directed towards supporting ecological agriculture (package 2), which burdens the environment in a small degree and ensures safe food production. The ecological production package, similarly to other agri-environmental programs, is subsidised from public resources. This is a form of recompensation for achieving smaller output in agricultural production (or for work executed for biological, environmental and scenic diversity). 
In Poland organic farming matters are governed by the Act on Organic Farming (Ustawa... 2009) and regulations under this Act issued by the Minister of Agriculture. The primary Act is the Council Regulation (EC) No. 834/2007 (Council of the European Union 2007) on organic production and labeling of organic products. The Act defines the tasks of public administration and business units in organic agriculture. These are, among others, farmers' obligations to observe the principles of good agricultural practice and other obligations arising from the implementation of agri-environment schemes.

One of the main goals of organic farming is striving to increase the fertility and biological activity of the soil by providing organic fertilizers, crop rotation and appropriate tillage limiting mineralization of organic matter. Support of agri-environmental activity bridges such fields as environmental protection and economy, which is compliant with the assumptions of sustainable development.

Organic farming is currently the subject of interest in many disciplines, not just natural and economic ones, but also social. Interest in organic agricultural production is growing in the world. This method of production first of all presents a chance of development for the poorer farms, provides management of surplus labour and improves the food supply in the local market, support economic development in rural communities (O'Hara, Parsons 2013). Organic farms are the object of study of many authors; however, most papers are focused on comparative analysis of production and economic results against the background of conventional farms (Lansink et al. 2002; Redlichova 2007; Offerman et al. 2009; Gardebroek et al. 2010; Nachtman 2010; Brožová 2011; Guesmi et al. 2012; Patil et al. 2014). The author of this article also conducted these types of studies (Koloszko-Chomentowska 2011). The influence of organic farm size on the results of management is not well known, and this is of large significance in Poland, because the area of arable land is the basic determinant of production size and economic results. Nachtman (2009) researched the role of subsidies in various area groups, but limited the analyses to the standard results described in FADN methodology. Similar studies were conducted in Czech organic farms (Hrabalová, Zander 2006). In both cases the indicators characterizing the ability of farms to operate in the long run were not included. Such information, in the opinion of this paper's author, is essential in deciding whether to switch from conventional production to organic one. A relatively small group of organic farms so far shows that even with farmers' full awareness about the superiority of organic production over conventional one, there is always the economic aspect in the background.

In order to fill this gap in knowledge, the aim of this work is to assess production and economic results of organic farms with various arable land surfaces including indicators that characterize the ability of farms to build production capacity in the future, as well as of the role of public funds in achieving these results.

\section{Material and methodology}

The undertaken research issue has been elaborated upon on the basis of data from organic farms in the Podlasie voievodeship, in the field of observation of the Polish Farm Accountancy Data Network. In the years 2008-2012, forty three such farms participated in this system. 
These farms possess organic farm certificates and simultaneously realize other agri-environmental programs. Production is varied as it includes the production of milk, poultry, grains, vegetables, and fruits. Data on farms was collected according to the methodology of the European Commission (Farm... 2010). Legally, data is collected by the Institute of Agriculture and Food Economics.

In this analysis, terms such as income and net added value are used in accordance with FADN nomenclature. Income from a family farmstead (SE420) constitutes the payment for involvement of own production factors in the operational activity of the farm and payment for the risk taken by the leader of the farm (in the analytical part, this is referred to as farm income). The income of a farm was taken as the primary measure of the farm results evaluation. The operational activity of a farm includes plant and animal production and other production types conducted on the farm. However, net added value (SE415) is the payment for permanent involvement of production factors without regard to their status of ownership (own or foreign) and constitutes a useful measure of income obtained by all owners of production factors involved in farm activity (Goraj et al. 2004).

A farm's financial result is the difference between the value of production and the costs incurred to obtain it. The production value (total output) includes the value of crop production, livestock production, and other production, which includes the provision of services with the use of farm resources and revenues from agri-tourism, not including operations and investment subsidies. According to Polish FADN methodology the total costs (total input) include: direct costs (crop production, livestock, and other production) and indirect costs. They include general economic costs (e.g. maintenance costs of buildings and equipment, energy, services, etc.), depreciation of fixed assets and the cost of external factors (remuneration of employees, lease payments and interest on loans).

The ability of farms to repay current liabilities was assessed on the basis of the current liquidity ratio according to the formula (Gabrusewicz 2002):

$$
\text { Current ratio }=\frac{\text { current assets }}{\text { short termliabilities }} \text {. }
$$

This ratio determines the ability of farms to settle the short-time liabilities with rotary means of production with no disturbance in their normal functioning. The optimal value of this ratio should be 1.5-2.0 (Gabrusewicz 2002). The value lower than 1.5 means difficulties in payments. In such a case, the farm should consider the possibility of obtaining cash from additional sources. Exceeding the upper limit of the ratio means the occurrence of financial over-liquidity that is excessive resource of inventories not used rationally.

In order to determine the prospects of farms functioning in the future their financial status and capital structure were examined. The re-investment fixed assets ratio was calculated with the following formula (Gołaś 2008):

$$
\text { Re-investment fixed assets ratio }=\frac{\text { net investment }}{\text { fixedassets }(\text { without land })} \times 100 .
$$

This ratio indicates the degree of the obtained assets reproduction. It informs what type of reproduction occurs in the farm (extended, straight, and narrowed). 
The ROE (Return on Equity) index was calculated as the relation of the financial result (net income) to own capital. Net income was calculated based on the difference between the income from farmstead and the labour costs of the farmer's own work (Gołaś 2008):

$$
R O E=\frac{\text { farm income }- \text { farmer's labourcost }}{\text { equity }} \times 100 .
$$

Calculation of this index required the estimation of costs of own work. The cost of work of a farmer and his family was appraised in the amount of a parity rate for 1 hour of work according to average yearly net remuneration in the national economy according to the data of the Central Statistical Office. $R O E$ ratio - expresses the effects of activity per unit of capital employed (farm ability to gain an income of one PLN own capital). The income per person employed on a farm was also related to the parity rate. Calculations were made according to actual financial operations. For the purposes of the analysis, farms were divided into area groups. The division was made according to the approximate value of the median (median $=20.29)$ : group I - farms with an area up to 20 ha (21 farms) and group II - farms with an area above 20 ha (22 farms). In this way, two groups of farms with different areas were obtained, which made it possible to realise the accepted goal of the work. Adoption of such a division seems to be justified because the dividing line is similar to the average size of organic farms which is 21 hectares in the Podlasie region.

The selection of the region was made purposely, this region was the Podlasie voievodeship. Podlaskie is one of the regions with high environmental values. Large forest cover and a significant share of permanent grassland determine that. It is estimated that over $50 \%$ of the region area has natural conditions relatively little changed by human activity (Biesiacki et al. 2004). This is the area known as the Green Lungs of Poland, characterized by the smallest environmental pollution in the country, which creates a chance for the development of organic agriculture. A specific trait of the Podlasie voievodeship is the presence of disadvantageous natural conditions for agricultural production. This is due, above all, to low soil quality and a short vegetation period. The indexation rate of the agricultural production area, being a synthetic measure of environmental quality, is 55 points, the lowest in the country (Stuczyński et al. 2000). Almost all municipalities (with the exception of three) have been counted into municipalities with unfavourable farming conditions. Historical factors have caused extensive forms of farming to dominate. Despite the unfavourable natural conditions, the agriculture of the Podlasie voievodeship produces $6.5 \%$ of national agricultural goods production and is placed at $6^{\text {th }}$ position in the country (Statistical... 2013).

\section{Organic farming in Poland}

In Poland in 2004 there were 3,760 organic farms, an area of 104,932 ha, and in 2012 there were 26,376 such farms, an area of 661,687 ha (Table 1). The share of organic farming in total crops area was $2.9 \%$. The meadows and green pastures have the largest share in the organic agricultural land. Production from livestock is dominated by dairy farming, beefcattle and pigs. Since Poland joined the EU the number of organic farms has increased more than 5 times. In terms of the organic farms number, Poland ranks $6^{\text {th }}$ in the European Union 
(Raport... 2013). Period 2007-2012 was characterized by preponderance of certified farms. In 2012, the certified farms accounted for $68.9 \%$ of all organic farms in Poland. The share of organic area was $3.5 \%$ of the total area of agricultural land in the country (Raport... 2013). The growing interest in organic production certainly is related to the financial support for this farming sector. The Rural Development Programme for 2007-2013 highlighted the promotion of agri-environment and market activities.

Table 1. Number of organic farms in Poland in years 2004-2012

\begin{tabular}{crccccc}
\hline & \multicolumn{2}{c}{ Total } & \multicolumn{2}{c}{ Certified farms } & \multicolumn{2}{c}{ Farms in conversion } \\
\cline { 2 - 7 } Years & Number & $\begin{array}{c}\text { Utilised } \\
\text { agricultural } \\
\text { area (ha) }\end{array}$ & Number & $\begin{array}{c}\text { Utilised } \\
\text { agricultural } \\
\text { area (ha) }\end{array}$ & Number & $\begin{array}{c}\text { Utilised } \\
\text { agricultural } \\
\text { area (ha) }\end{array}$ \\
\hline 2004 & 3,760 & $104,932.2$ & 1,683 & $44,817.2$ & 2,077 & $58,115.0$ \\
2005 & 7,182 & $166,299.7$ & 1,463 & $38,672.7$ & 5,719 & $127,627.0$ \\
2006 & 9,187 & $228,009.1$ & 3,504 & $75,090.7$ & 5,683 & $152,918.4$ \\
2007 & 11,870 & $287,528.4$ & 6,618 & $137,890.8$ & 5,252 & $150,380.3$ \\
2008 & 14,896 & $314,921.2$ & 8,685 & $178,732.2$ & 6,211 & $136,189.0$ \\
2009 & 17,423 & $416,261.3$ & 10,153 & $252,790.9$ & 7,270 & $163,470.4$ \\
2010 & 20,956 & $519,068.4$ & 12,901 & $308,094.7$ & 8,055 & $210,973.7$ \\
2011 & 23,847 & $605,519.6$ & 15,234 & $376,035.9$ & 8,613 & $229,483.7$ \\
2012 & 26,376 & $661,687.2$ & 18,187 & $457,088.5$ & 8,189 & $204,598.7$ \\
\hline
\end{tabular}

Source: Kłos (2011), Raport... (2011, 2013).

\section{Results of the own study}

Data characterizing the studied farms shows that organic production is being led by small and large farms alike. Farm diversification in terms of production factors (Table 2) is indicative of this. Total employment in farms ranged from 0.87 to 2.63 fully employed persons, with a small share of a hired workforce. Large diversity was visible in the technical means of production of farms, with asset variability from 93.29 thousand PLN (group I) to 807.34 thousand PLN (group II). Even greater diversity was present in terms of utilized agricultural area, with the farm with the smallest utilised agricultural area being 8 times smaller than the largest farm. The consequence of production factor diversity is the economic size of farms ranging from minimum 2.05 ESU (very small farm) to maximum $49.02 \mathrm{ESU}$ (large farm) ${ }^{*}$.

All farms made use of subsidies from European Union funds. These farms received nearly 2.2 million PLN in total during the years 2008-2012. Agri-environmental subsidies dominate the subsidy structure (Table 3 ). This data confirms the fact that farmers using environment-friendly methods utilise the chances that the current agricultural policy creates for them. These farms produce organic food and also realise other agri-environmental programs, which is shown by the share of subsidies for activities improving the welfare of farm animals. This is especially significant in farms with larger areas, where the average number of animals is nearly twice as large as in farms with area up to 20 ha UAA (group I - 7.65;

\footnotetext{
* European Size Unit - European unit of size.
} 
group II - 14.42 LU). Programs supporting afforestation of arable land also play an important role. In the studied population, such programs were only realised in farms with area above 20 ha (Table 3 ).

Table 2. Characteristic of organic farms in the years 2008-2012

\begin{tabular}{|c|c|c|c|c|}
\hline \multirow[b]{2}{*}{ Description } & \multicolumn{4}{|c|}{ Descriptive statistics } \\
\hline & Average & Min. & Max. & $\begin{array}{l}\text { Standard } \\
\text { deviation }\end{array}$ \\
\hline \multicolumn{5}{|c|}{ Group I (up to 20 ha) } \\
\hline Economic size $\left(\mathrm{ESU}^{1}\right)$ & 6.22 & 2.05 & 12.78 & 2.191 \\
\hline Total UAA ${ }^{2}$ (ha) & 13.96 & 8.01 & 19.10 & 4.227 \\
\hline Total labour input $\left(\mathrm{AWU}^{3}\right)$ & 1.68 & 0.87 & 2.70 & 0.546 \\
\hline Family work $\left(\mathrm{FWU}^{4}\right)$ & 1.65 & 0.87 & 2.63 & 0.551 \\
\hline Fixed assets (thousands PLN) & 175.62 & 93.29 & 358.13 & 68.719 \\
\hline Equity - net worth (thousands PLN) & 216.37 & 110.11 & 421.11 & 83.828 \\
\hline \multicolumn{5}{|c|}{ Group II (20 ha and more) } \\
\hline Economic size (ESU) & 17.16 & 3.51 & 49.02 & 10.512 \\
\hline Total UAA (ha) & 34.79 & 21.92 & 69.19 & 15.188 \\
\hline Total labour input (AWU) & 1.63 & 1.00 & 2.51 & 0.473 \\
\hline Family work (FWU) & 1.61 & 1.00 & 2.51 & 0.471 \\
\hline Fixed assets (thousands PLN) & 342.46 & 108.27 & 807.34 & 171.667 \\
\hline Equity - net worth (thousands PLN) & 380.49 & 142.14 & 818.02 & 165.135 \\
\hline
\end{tabular}

${ }^{1}$ European Size Unit - European unit of size;

${ }^{2}$ Utilised agricultural area;

${ }^{3}$ Annual Work Unit - conversion unit for work in general;

${ }^{4}$ Family Work Unit - conversion unit for work of family members.

Source: own calculations based on FADN (2010) data.

Table 3. Value and structure of subsidies in the years 2008-2012

\begin{tabular}{lcc}
\hline \multirow{2}{*}{ Description } & \multicolumn{2}{c}{ Farms } \\
\cline { 2 - 3 } & Group I (up to 20 ha) & Group II (20 ha and more) \\
\hline Total subsidies (PLN/group) including: (\%) & $489,636.56$ & $1717,496.80$ \\
a) area grants & 36.5 & 37.0 \\
b) agri-environmental subsidies including: & 45.7 & 37.1 \\
- organic production & 89.7 & 93.3 \\
- other & 10.3 & 6.7 \\
c) subsidies on Less-Favoured Areas (LFA) & 14.9 & 14.4 \\
d) investment & 0.0 & 4.8 \\
e) other & 2.9 & 6.7 \\
- including: afforestation of arable land & 0.0 & 56.3 \\
Total subsidies per farm (PLN) & $17,487.02$ & $49,071.34$ \\
Total subsidies per 1 ha (PLN) & $1,252.65$ & $1,410.57$ \\
Total subsidies per 1 ha (EUR ${ }^{1}$ ) & 304.51 & 342.89 \\
Agri-environmental subsidies per 1 ha (PLN) & 618.17 & 504.53 \\
Agri-environmental subsidies per 1 ha (EUR) & 141.93 & 122.64 \\
\hline
\end{tabular}

${ }^{1}$ conversion to EUR carried out according to the exchange rate used during charging of subsidies by the Agency for Restructuring and Modernization of Agriculture in 2012.

Source: own calculations based on FADN (2010) data. 
Direct payments (area grants) take second place. The popularity of this instrument is due to the fact that receiving funds is not connected with the necessity for documenting their purpose and does not require great effort from the farmer as regards formalities. Support for farming in unfavourable conditions (LFA) had a smaller share in the subsidy structure. This is a very important activity, the purpose of which is to maintain a sustainable method of farming with consideration of environmental protection principles and maintenance of vitality of rural areas.

Farms of both researched groups differed in the structure of their production (Table 4). In the spatially smaller farms (up to 20 ha) livestock production dominated, its share in the total output was $52.6 \%$, crop production accounted for $46.4 \%$, while revenues from the rest of the production were negligible. The difference in the total output of 1 ha utilised agricultural area may be due to several factors. The probable cause is the intensity of agricultural production and farm type. Farms in group I focused more on animal production, which is more capital-intensive, but it allows farmers to achieve higher sales price than the unprocessed plant products. The higher intensity is also noticeable in the cost incurred on 1 ha (Table 5). The production output could also be affected by the soil quality, which in group I was 0.59 points and in group II -0.47 pts. That should be considered low quality of soil since in Poland the average value of the index is 0.79 points.

Table 4. Selected information about production of organic farm in the years 2008-2012 (per farm)

\begin{tabular}{lcc}
\hline \multirow{2}{*}{ Description } & \multicolumn{2}{c}{ Farms } \\
\cline { 2 - 3 } & Group I (up to 20 ha) & Group II (20 ha and more) \\
\hline Total output (PLN) including: & $39,838.94$ & $52,230.95$ \\
crop production (PLN) & $18,469.41$ & $27,117.13$ \\
animal production (PLN) & $20,957.12$ & $21,097.62$ \\
other production (PLN) & 412.41 & $5,016.20$ \\
including: agri-tourism (PLN) & 193.20 & $3,731.65$ \\
Total output per 1 ha (PLN) & $2,853.79$ & $1,501.32$ \\
\hline
\end{tabular}

Source: own calculations based on FADN (2010) data.

Higher diversification of production was observed in farms of farmland over 20 ha. First of all, a predominance of crop production can be noticed. It probably resulted from the desire to simplify the farm organization and reduce farm labour. Apart from the basic sectors (crop and livestock) some additional production was also conducted on the basis of farm resources, the share of which was $9.6 \%$ in the value of total output, including $74.4 \%$ of revenues from agri-tourism. This information testifies to the fact that owners of large farms are more entrepreneurial than owners of smaller ones. Actions to prevent the risk of failure in one area of activities are taken that engage the resources into some alternative activities. The owners of smaller farms are more distant to such activities.

The financial result of a farm is formed by its revenues and costs incurred (total inputs). There is a close correlation between these values. Material costs per 1 hectare were taken as a measure of the production intensity. They include the costs directly associated with the production and a part of indirect costs, which are costs of supply for farm operations. They were higher in smaller farms (group I - Table 5). This indicates a higher intensity of manage- 
ment, which is probably due to the dominance of livestock production in the structure of the total output, which is more capital-intensive. Material costs constituted almost $70 \%$ of total costs and their structure was dominated by the direct costs. The structure of direct costs in both groups was similar. The dominance of feed costs (71.97-75.23\%) can be observed. Those costs were feed for farm animals fed in the grazing system and those of grain-eating animals. In group II there was a greater share of the costs of buying seed. This was due to a greater share of crop production in the structure of farms with an area of over 20 hectares

Only a slight expenditure on fertilisers and pesticides was included in the direct costs. This is understandable because on these farms the need for fertilisation is satisfied by organic fertilisers, and care work is done manually or mechanically.

Table 5. Selected information about total inputs of organic farms in the years 2008-2012 (per farm)

\begin{tabular}{lcr}
\hline \multirow{2}{*}{ Description } & \multicolumn{2}{c}{ Farms } \\
\cline { 2 - 3 } & Group I (up to 20 ha) & Group II (20 ha and more) \\
\hline Total inputs (PLN) including: & $37,025.21$ & $55,180.65$ \\
- direct costs ${ }^{1}(\%)$ & 33.52 & 29.13 \\
- indirect costs ${ }^{2}(\%)$ & 66.48 & 70.87 \\
Total inputs per 1 ha (PLN) & $2,652.24$ & $1,586.11$ \\
Material costs per 1 ha (PLN) & $1,832.79$ & $1,074.67$ \\
Direct costs per 1 ha (PLN) including: & 889.03 & 462.03 \\
- seeds (\%) & 11.41 & 15.84 \\
- mineral fertilizers (\%) & 2.52 & 7.98 \\
- feed (\%) & 75.23 & 71.97 \\
- others (\%) & 10.84 & 10.21 \\
\hline
\end{tabular}

1 total specific costs;

2 total farming overheads, depreciation, total external factors.

Source: own calculations based on FADN (2010) data.

The ratio of liquidity also informs about the farm's ability to function in the market. The data presented in Table 6 indicate that in both of the compared groups the ratio of current liquidity was significantly different from the optimal value. What is the cause? An unequivocal answer is not obvious because in agriculture there is a slow turnover of capital. Funds invested in current assets are returned only after the completion of a production cycle, which is long. So there is no possibility of early disposal of the asset, even if it is indicated in the account. From an accounting point of view, it can be assumed that the owners invested too little in their farms' development, especially in smaller farms (up to 20 ha) as the ratio of liquidity was much higher there. These assumptions can be partially confirmed by the value of the net investment and the rate of reproduction of fixed assets. It turned out that only larger farms (group II) had the ability to reproduce their used assets. In this case only, the value of gross investment was higher than the amount of depreciation, so there was extended reproduction, although it was not a high rate $(0.98 \%)$. With smaller farms (group I) the assets reproductive rate was in the negative $(-8.57 \%)$. The fixed assets were not reproduced, as was indicated by the value of gross investment, and this means a narrower reproduction. Perhaps the units lacked their own resources for investment activities and they might not have had the credit capacity to take advantage of external financing. That is indicated by more than 3 times 
Table 6. Characteristics of the property and the financial position of organic farms in the years 2008-2012 (per farm)

\begin{tabular}{|c|c|c|}
\hline \multirow{2}{*}{ Description } & \multicolumn{2}{|c|}{ Farms } \\
\hline & Group I (up to 20 ha) & Group II (20 ha and more) \\
\hline Total assets (PLN/farm) including: & $218,905.17$ & $411,860.40$ \\
\hline - fixed assets $(\%)$ & 80.22 & 83.87 \\
\hline - current assets $(\%)$ & 19.78 & 16.13 \\
\hline Total assets per 1 ha UR (PLN) & $15,680.89$ & $11,838,47$ \\
\hline Fixed assets per 1 ha UR (PLN) & $12,579.21$ & $9,931.34$ \\
\hline Equity (PLN/farm) & $216,372.51$ & $380,486.68$ \\
\hline Liabilities (PLN/farm) & $6,498.62$ & $31,374.76$ \\
\hline - short-term liabilities ${ }^{1}$ (PLN/farm) & $2,268.02$ & $7,264.17$ \\
\hline - long-term liabilities² (PLN/farm) & $4,230.60$ & $24,110.59$ \\
\hline Gross investments (PLN/farm) & $-1,287.15$ & $66,151.24$ \\
\hline Depreciation (PLN/farm) & $9,626.53$ & $63,765.63$ \\
\hline Net investments (PLN/farm) & $-10,913.68$ & $2,385.61$ \\
\hline Current ratio & 19.09 & 9.15 \\
\hline Liabilities ratio $(\%)$ & 2.97 & 7.62 \\
\hline Re-investment fixed assets ratio (\%) & -8.57 & 0.98 \\
\hline
\end{tabular}

lower - in relation to the larger farms - level of indebtedness of these farms. On the other hand - investment opportunities primarily depend on the level of income. If this is low or very low, there is no objective opportunity for investment and development. The relation of the farm size and its investments is well known in Polish agriculture. Small farms do not often show interest in investing activities. Whereas farms of large production capacity are generally strong economically and they understand the need to invest much better, as well as the necessity to maintain a competitive position.

The difficulties in the re-investment fixed assets result also from the adverse relations in the structure of assets. In the surveyed farms the share of fixed assets in total assets was very high (80.22-83.87\%). Such a high share of fixed assets never provides high capital efficiency; it also makes it difficult to reproduce the value of the assets. These difficulties arise from the fact that during the production cycle the fixed assets transfer only a part of their value to the finished product, and therefore there is the need for more production cycles to reproduce them. Such a structure of production assets, despite being unfavourable due to the negative impact on the possible renewing of the capital, is typical of many farms in Poland. The structure of the surveyed farms' assets was not advantageous, which was reflected in not the best economic results. In this group the value of subsidies was higher than the earned income.

Income from the farm should provide, that is to give, the farming family an acceptable social level and accumulation in specific political conditions. The level of income from agricultural activity is a derivative of many factors, where public funds are also playing an important role. The data shown in Table 7 shows that production and economic results of studied farms were dependent on the size of the farm. 
Table 7. Economic results of organic farms in the years 2008-2012 (per farm)

\begin{tabular}{|c|c|c|c|c|}
\hline \multirow[b]{2}{*}{ Description } & \multicolumn{4}{|c|}{ Descriptive statistics } \\
\hline & Average & Min. & Max. & $\begin{array}{l}\text { Standard } \\
\text { deviation }\end{array}$ \\
\hline \multicolumn{5}{|c|}{ Group I - farms with areas up to 20 ha UAA } \\
\hline Total output (PLN) & $39,838.94$ & $4,309.53$ & $122,265.34$ & $27,265.225$ \\
\hline Total output per 1 ha (PLN) & $2,853.79$ & $1,211.94$ & $3,985.73$ & 649.083 \\
\hline Net value added (PLN) & $24,403.82$ & $1,374.07$ & $98,871.29$ & $19,774.481$ \\
\hline Net value added per 1 ha (PLN) & $1,748.12$ & 728.12 & $3,835.67$ & 986.821 \\
\hline Total family farm income (PLN) & $22,327,91$ & $-3,484.28$ & $66,866.33$ & $16,234.467$ \\
\hline Family farm income per 1 AWU (PLN) & $14,537.08$ & $1,272.20$ & $50,045.21$ & $11,789.662$ \\
\hline Family farm income per 1 FWU (PLN) & $13,539.16$ & $-2,247.93$ & $462,491.89$ & $14,094.183$ \\
\hline Family farm income per 1 ha (PLN) & $1,599.93$ & -98.47 & $3,427.61$ & 929.644 \\
\hline $\begin{array}{l}\text { Family farm income per } 100 \text { PLN } \\
\text { of fixed assets (PLN) }\end{array}$ & 12.71 & -0.32 & 29.60 & 9.170 \\
\hline Share of subsidies in family farm & & & & \\
\hline income (\%) & 98.32 & 0.00 & 199.35 & 48.871 \\
\hline Return on equity $R O E(\%)$ & 1.02 & -27.13 & 11.48 & 7.638 \\
\hline \multicolumn{5}{|c|}{ Group II - farms with areas of 20 ha UAA and above } \\
\hline Total output (PLN) & $52,230.95$ & $9,632.10$ & $293,564.01$ & $47,428.634$ \\
\hline Total output per 1 ha (PLN) & $1,501.32$ & 621.84 & $4,562.18$ & 98.361 \\
\hline Net value added (PLN) & $46,022.91$ & $-41,116.82$ & $295,512.06$ & $59,164.016$ \\
\hline Net value added per 1 ha (PLN) & $1,322,88$ & 289,03 & $3,516.59$ & 593.626 \\
\hline Total family farm income (PLN) & $43,117.53$ & $-41,316.79$ & $269,588.11$ & $55,362.147$ \\
\hline Family farm income per 1 AWU (PLN) & $28,234.94$ & $-12,558.40$ & $114,540.09$ & $306,662.220$ \\
\hline Family arm income per 1 FWU (PLN) & $26,781.07$ & $-12,558.40$ & $104,492.73$ & $29,199.271$ \\
\hline Family farm income per 1 ha (PLN) & $1,240.38$ & -543.13 & $3,652.97$ & 902.125 \\
\hline $\begin{array}{l}\text { Family farm income per } 100 \text { PLN } \\
\text { of fixed assets (PLN) }\end{array}$ & 12.48 & -0.17 & 97.25 & 27.943 \\
\hline Share of subsidies in family farm & & & & \\
\hline & 113.81 & 41.17 & 168.92 & 227.953 \\
\hline Return on equity $R O E(\%)$ & 4.86 & -31.69 & 47.31 & 15.162 \\
\hline
\end{tabular}

Source: own calculations based on FADN (2010) data.

The value of realised production (total output) and family farm income are higher in farms of group II, which is understandable because these values are derived from a greater number of production factors in those farms. However, for production value per 1 ha, the net added value and income were higher in the farms of group I. This is the result of greater farming intensity in smaller farms.

The value of income in relation to the farm does not give a full picture of the material situation of a farming family. The level of income in relation to a person that is fully employed in the farm is important. In the case of farms with an area of up to 20 ha, income per fully employed person constituted only $51.5 \%$ of the income obtained in farms with higher areas, with large variability depending on a given farm. The range of variation of this index was from 1,272.20 PLN (309.24 EUR) to 50,045.21 PLN (12,165.20 EUR). A greater variability was observed in farms of group II, in the extreme case, the net added value and farm income took on negative values while the maximum values of these economical values were over three times larger than the average values for the entire population. It should be noted that 
lower level of income per person in small farms (group I) is in part due to the accumulation of labour resources in the absence of alternative employment. In small farms we find hidden unemployment. This does not change the fact that there is a problem of maintaining an appropriate level of consumption as well as the accumulation of labour resources in these farms. However, in big farms, better equipped with capital, labour productivity is higher.

A more objective picture will be achieved if the level of income per hour of work of a farmer and his family is related to the average net remuneration in the national economy. From this point of view, income in group I farms constituted $62.63 \%$ and in group II $-94.14 \%$ of parity income. Simultaneously, it can be noted that achievement of such a level of income would be impossible without subsidies for operating activities, the share of which was very high due to the fact that it was at $98.32 \%$ in group I and more than $113 \%$ in group II, which means that the value of the subsidies was higher than the income. In the case of both groups, subsidies fulfilled a social role, which means that these farms functioned on the basis of subsidies. If there were no subsidies, there would be no funds to pay for production factors and the income would be very low or negative.

The return on equity index plays an important role in assessing the financial situation of a farm. This index specifies the level of income per unit of own involved capital. The higher the return on equity, the more favourable the developmental perspectives of the farm, and the greater the number of resources that can be assigned to development. Farms of group II were characterized by a higher return on equity, with $R O E$ at $4.86 \%$, which was over four times higher than for group I farms, which indicates greater developmental perspectives for group II farms. This interpretation may be questionable, because ROE indicates the ex-post situation. It can also be used to assess future events, but it should be used with caution.

\section{Discussion}

Supporting agricultural farmsteads with public funds is one of the important assumptions of the Common Agricultural Policy, the aim of which is to restructure the agricultural sector on one hand, and on the other, sustainable and constant development of agriculture and rural areas. Parts of the economic instruments do not stimulate an increase in agricultural production; however, due to these instruments having the form of transfers to agricultural farmsteads, they influence agricultural income.

A farm is an essential component of agriculture. The basis for its endurance as a system is to maintain at least an intact ecosystem and the sustainable ability to achieve revenue (Majewski 2008). This economic aspect is so important because it determines the material conditions of life for farm families and it becomes a basis for choosing the way of life and thus determines the behaviour of economic and social sustainability of rural areas.

Polish agriculture inclusion to the mechanisms of the Common Agricultural Policy means support for both commercial farms with strong ties to the market and farms that realise new functions, such as organic farming, seeing their chances in searching alternative sources of income. Organic farming is a system of the market and just like any business is subject to competition rules. Therefore the farmers are required, on the one hand, to know the management principles in accordance with the requirements of environmental protection 
(which have nothing in common with the primitive methods of farming, on the contrary, new knowledge and experience in dealing with nature is essential) and on the other hand to know the market rules as they determine their existence. In this situation, it is important to have the skills to assess the perspectives of economic development by the farmer since he is the one who takes the risks of the business.

Polish agriculture (including organic farming) has benefited from public support after accession to the European Union. Since then, a very dynamic growth in the number of farms and organic area has been observed, which would not be possible without an external support system. Rapid growth in the number of organic farms is reflected in the increase in the supply of high quality products. Despite the increase in the number of organic farms, the natural and economic conditions beneficial for production of this type are still not fully used (Kłos 2011). More time-consuming and less productive organic farming probably does not encourage farmers to shift to this production system, as the number of organic farms is relatively small. In addition, research shows that most consumers believe organic products too expensive and difficult to obtain, which also hinders the expansion of organic farming (O’Donovan, McCarthy 2002; Hughner et al. 2007; Aertsens et al. 2009). Most of the consumers are willing to accept a price about by $10 \%$ higher than that of traditional foods (Zámková, Blašková 2013). There is also a trend of farms that leave the organic sector by converting back to conventional methods. In Germany between 2007 and 2010 every eleventh organic farm returned to conventional agriculture (Heinze, Vogel 2012).

The total output in the surveyed farms was relatively low. Similar results were obtained in studies carried out in the same farms in 2005-2007, in comparison to the conventional farms of the region. Then the total output of organic farms accounted for $30.6 \%$ of the conventional farms total output (Koloszko-Chomentowska 2011). Similar results were obtained by Nachtman conducting research on organic farms in the FADN system (Nachtman 2010).

Organic farming in Poland is likely to become an important element in the development of Polish agriculture in the direction of sustainable development. The traditional character of Polish countryside, i.e. dominance of family farms of a small area, their high fragmentation, suitable soil and climate conditions, the large workforce and low labour costs, and above all, the low level use of chemicals - support its expansion. This relates especially to the regions where environmental conditions and low level of industrialisation, and thus low environmental pollution, support its development.

As conducted studies show, public funds constitute the main source of income for farming families realising many tasks for environmental protection. Funds transferred through programs supporting such activities do not signify direct support of agricultural income, but constitute gratification for actions protecting the environment. In practice, as it turns out, these funds constitute material indemnity of agricultural families. This is also confirmed by other studies, e.g. in the structure of revenue of ecological farms of Lower Silesia; subsidies also had a decisive share, from $37 \%$ to $54 \%$ (Golinowska 2008). In research on organic farms in the years 2005-2008 the share of subsidies in farm income was more than 58-91\% (Nachtman 2011). Research carried out in the EU shows that the share of subsidies in the income of organic farms in all of the countries is significant and amounts to $10-30 \%$, and in some countries of Eastern Europe after the EU accession it has risen to three-quarters. In the 
farmers' opinion payments on organic farming were considered important to the viability of the farm in the new Member States more often than in Western Europe (Zander et al. 2008; Offerman et al. 2009).

The role of public funding varies depending on the area of the farm. Per capita income in group I farms was 3,533.73 EUR (14,537 PLN) and accounted for only $51 \%$ of the income in group II farms. The share of subsidies in the group I farms income was $98.3 \%$ and in the group II - 113.8\%. In the previous period of studies (2005-2007) the income earned by organic farms accounted for $65 \%$ of the income in the conventional ones and the share of subsidies amounted to $92.1 \%$ in organic farms and $38.1 \%$ in the conventional farms (Koloszko-Chomentowska 2011). Correlation of the economic results and area of farms was also revealed by other studies, for example in big organic cattle farms in the Czech Republic, income from the farm of 1 AWU was higher than the statistical income, and in small dairy farms it was several times lower, even with subsidies of nearly 80\% (Hrabalová, Zander 2006).

Studies conducted in the Czech Republic indicate that economic results of organic farms were similar to those for conventional farms, and the attainment of such a level was possible thanks to subventions for ecological production (Redlichova 2007). In farms with cattle breeding the subsidies accounted for $50-75 \%$ of total revenues (Hrabalová, Zander 2006). The scope and level of subventions became an encouragement for the dynamic development of organic methods of production in the Czech Republic (Jánský, Živělová 2006; Łapińska 2009). Return on equity in Czech organic farms in 2001 was slightly lower than in conventional farms, but in 2005, the value of this index was similar for both farm groups and was only slightly above $10 \%$ (Redlichova 2007). Other studies indicate that economic results of organic farms are more favourable than the conventional farms (Brožová 2011; Guesmi et al. 2012; Patil et al. 2014). But it should be taken into account that economic results depend on the type of farms (Franckes, Latacz-Lohmann 2008).

In studied organic farms of the Podlasie region, return on equity was significantly lower, however the positive (1.02\% and $4.86 \%)$ return on equity in larger farms was, in areas, even higher than for conventional farms ( $R O E$ in conventional farms 4.79\%) (Koloszko-Chomentowska 2011).

The capital is a source of financing assets. The risk borne by the farm business can be determined by the share of own capital in financing of the assets. It is generally accepted that the higher the share is, the lower the risk. In the case of small farms the optimal level of assets financing with own capital is considered at $75 \%$. In the surveyed farms the level was much higher, ie. $92-97 \%$ of the total assets were financed with own capital. Therefore it can be concluded that the surveyed farms benefited too little from the loans either for investment purposes or current ones, thus limiting their potential for development. The previous research also confirmed limited investments in farms of small economic potential (Koloszko-Chomentowska 2003). It is worth noting that the subsidies for investments were used only by farms from group II (Table 3).

The reluctance of farmers to use external financing (mainly loans) is fairly common, and not only in Poland. Similar behaviour of farmers is observed in Bulgaria, Romania and Mexico (Hertz 2009; Pfeiffer et al. 2009): high and changeable interest rates, high collateral requirements of banks for loans and too-short terms of repayment are considered the main barriers. 
To compete successfully the farms must meet the challenges of production process modernisation. Factors leading to the modernisation of agriculture are penetration into the farms of widely understood agricultural innovations that contribute to increasing the modernity of level manufacturing techniques, knowledge, qualifications and skills of farm management. Organic farms, as well as conventional ones, require modernisation changes and adaptation of technological innovation. However, these processes are slower than expected, especially when it comes to conversion from conventional to organic production. A similar phenomenon has also been observed in Germany and Austria (Musshoff, Hirschauer 2008). The role of public resources is particularly important for the functioning of small farms, both in their current operations and making investments. An important role is played by subsidised credits (from public funds), which allow for faster adaptation of new technologies. This is confirmed by studies carried out in India where the government subsidies have contributed to the development of investment in agriculture and rural poverty reduction (Fan et al. 2008). In the surveyed farms the largest part in the structure of commitments constituted preferential loans; they are a form of national state aid for farms. In farm group II they accounted for $85 \%$. Dominant share of preferential loans in the agricultural indebtedness is also confirmed by other studies (Grzelak 2005; Koloszko-Chomentowska 2012).

The studies of organic farms in Podlasie, as well as the studies of other authors (Zander et al. 2008; Offerman et al. 2009; Darnkofer et al. 2010; Nachtman 2010) indicate that subsidies in the framework of agri-environmental programs have a large significance for the functioning of organic farms. These farms not only produce using environment friendly methods, but also care for animal welfare, and the preservation of genetic resources and the landscape. An agreement was reached in the European Union as to the fact that a farmer should not be supported for producing a lot of market goods, but for the way he produces them and whether the farmer is a good supporter of natural and cultural resources of society. Therefore the emphasis was shifted on supporting farmers who produce good quality agricultural products and observe the principles of environmental protection. Current activities related to the implementation of the Common Agricultural Policy evidence that. They primarily involve linking direct payments with cross compliance rules, and enhancing the role and financing of rural development under the Rural Development Plan.

Organic farms realise many important functions in maintaining the natural environment, and that is why supporting these farms with public funds is justified. There are also opinions that agri-environmental programs have a limited influence on European agriculture, mainly for the reason of low interest by farmers in these programs (Espinose-Goded et al. 2010).

\section{Conclusions}

1. Public funds directed to organic farms have caused significant improvement of the economic situation, although income parity has not been achieved. However, depriving these farms of this form of support, in the extreme case, would cause their negative financial result.

2. Public funds had a visibly greater effect in farms with arable land areas above 20 ha. The income per fully employed person in the farm was almost two times higher, and the return 
on equity more than three times higher than in smaller farms. Such a result was determined also by other factors, but certainly managers of these farms are more active in obtaining external funding from various sources, maintaining greater diversification of production thereby reducing the risk of failure, which affected the financial performance of farms.

3. Reproduction ratios of assets and debts indicate little activity by farmers towards modernisation and development, despite the fact that favourable results were achieved by spatially larger farms. Only the larger farms have benefited from the state public aid in the form of preferential loans. Farms in both groups benefited little from bank loans mainly for investment activities, which greatly reduced their development. Higher activity would be recommended related to the use of external sources of financing, including commercial credit. It should be noted, however, that the decision about investments is always dictated by personal conditions of the farmer and his family.

4. Spatially small farms did not have the abilities to reproduce their assets. This confirms the high load of the fixed assets on the farms. Rational use of assets through lease or sale of part of them or collective use of the available resources is recommended.

5. Improvement of farm income would take place in the case of increased demand for organic products. This is rather difficult to achieve in the current economic conditions in Poland. Demand for organic products is positively correlated with the level of social wealth, and in conditions of economic crisis, there are limited prospects for expansion of organic farms onto the market.

6. Organic farms following the concept of sustainable development help to protect the environment, provide environmental public goods used by the whole society, which is why the development of organic farming should be supported. The extent of this support remains an open question.

\section{References}

Aertsens, J.; Verbeke, W.; Mondelaers, K.; Van Huylenbroeck, G. 2009. Personal determinants of organic food consumption, British Food Journal [online] 11(10): 1140-1167 [cited 15 July 2012]. Available from Internet: http://bazy.pb.edu.pl:2168/journals.htm?articleid=1816958\&show=abstract

Barbier, E. B. 1987. Concept of sustainable economic development, Environmental Conservation 14(2): 101-110. http://dx.doi.org/10.1017/S0376892900011449

Bartolini, F.; Gallerani, V.; Raggi, M.; Viaggi, D. 2005. Contract design and targeting for the production of public goods in agriculture: the impact of the 2003 CAP reform, in Proc. of the International Congress European Association of Agricultural Economists [online], 23-27 August 2005, Copenhagen, Denmark. 12 p. [cited 15 July 2012] Available from Internet: http://purl.umn.edu/24559

Benckiser, G. 2010. Ants and sustainable agriculture, Agronomy for Sustainable Development [online] 30(2): 191-199 [cited 22 July 2012 ]. Available from Internet: http://dx.doi.org/10.1051/agro/2009026

Biesiacki, A.; Kus, J.; Madej, A. 2004. Ocena warunków przyrodniczych do produkcji rolnej woj. Podlaskie [Evaluation of natural conditions for agricultural production Podlasie voievodeship]. Instytut Uprawy Nawożenia i Gleboznawstwa -Państwowy Instytut Badawczy, Puławy. 54 p.

Brožová, I. 2011. The economic performance analysis of organic farms in the Czech Republic, Agricultural Economics [online] 57(5): 240-246 [cited 12 September 2012]. Available from Internet: http://www. agriculturejournals.cz/publicFiles/40670.pdf 
Council of the European Union. 2005. Council Regulation (EC) No. 1698/2005 [online], [cited 15 July 2012]. Available from Internet: http://eur-lex.europa.eu/LexUriServ/LexUriServ.do?uri=OJ:L:20 05:277:0001:0040:EN:PDF

Council of the European Union. 2007. Council Regulation (EC) No. 834/2007 [online], [cited 15 July 2012]. Available from Internet: http://eur-lex.europa.eu/LexUriServ/LexUriServ.do?uri=OJ:L:20 07:189:0001:0023:EN:PDF

Daly, H. E.; Cobb, Jr. J. 1989. For the common good: redirecting the economy toward community, the environment and sustainable future. Boston: Beacon Press. $492 \mathrm{p}$.

Darnkofer, I.; Lindenthal, T.; Bartel-Kratochvil, R.; Zollitsch, W. 2010. Conventionalisation of organic farming practices: from structural criteria towards an assessment based on organic principles, Agronomy for Sustainable Development 30(1): 67-81. http://dx.doi.org/10.1051/agro/2009011

Espinose-Goded, M.; Barreiro-Hurle, J.; Ruto, E. 2010. What do farmers want from agrienvironmental Scheme Design? A choice experiment approach, Journal of Agricultural Economics 61(2): 250-273. http://dx.doi.org/10.1111/j.1477-9552.2010.00244.x

Fan, S.; Gulati, A.; Thorat, S. 2008. Investment, subsidies and pro-poor growth in rural India, Agricultural Economics 39(2): 163-170. http://dx.doi.org/10.1111/j.1574-0862.2008.00328.x

Farm Accountancy Data Network (FADN). 2010. Farm Accountancy Data Network: An A to Z of methodology [online]. European Commission [cited 12 May 2012 ]. Available from Internet: http://ec.europa.eu/agriculture/rica//pdf/site_en.pdf

Franckes, T.; Latacz-Lohmann, U. 2008. Exploring differences in financial success of organic farms in Germany: an empirical analysis, Berichte Uber Landwirtschaft [online] 86(2): 204-225 [cited 10 September 2012]. Available from Internet: http://bazy.pb.edu.pl:2749/full_record.do?product=UA\&search_mo $\mathrm{de}=$ GeneralSearch\&qid $=1 \&$ SID $=$ P16NAoEDOcdIGcbi7aK\&page $=2 \&$ doc $=12$

Gabrusewicz, W. 2002. Podstawy analizy finansowej [Basic financial analysis]. Warszawa: Polskie Wydawnictwo Ekonomiczne. 253 p.

Gardebroek, C.; Chavez, M. D.; Lansink, A. O. 2010. Analysing production technology and risk in organic and conventional Dutch arable farming using panel data, Journal of Agricultural Economics 61(1): 60-75. http://dx.doi.org/10.1111/j.1477-9552.2009.00222.x

Golinowska, M. 2008. Efekty produkcyjno-ekonomiczne gospodarstw ekologicznych Dolnego Śląska [Production and economic results of the organic farms in Lower Silesia Region], Roczniki Naukowe Stowarzyszenia Ekonomistów Rolnictwa i Agrobiznesu 10(3): 151-154.

Gołaś, Z. 2008. Uwarunkowania rentowności kapitału własnego w rolnictwie, część II [Conditions for the return on equity of agriculture, part II], Zagadnienia Ekonomiki Rolnej 4(312): 73-93.

Goraj, L.; Mańko, S.; Sas, R.; Wyszkowska, Z. 2004. Rachunkowość rolnicza [Agricultural accounting]. Warszawa: Wyd. Difin. 320 p.

Grzelak, A. 2005. Finansowanie zewnętrzne gospodarstw rolnych [Forms of external financing of farms], Wieś i Rolnictwo 4(129): 116-123.

Guesmi, B.; Serra, T.; Kallas, Z.; Gil Roig, J. M. 2012. The productive efficiency of organic farming: the case of grape sector in Catalonia, Spanish Journal of Agricultural Research 10(3): 552-566. http://dx.doi.org/10.5424/sjar\%2F2012103-462-11

Heinze, S.; Vogel, A. 2012. Determinants for the adoption and abandonment of organic farming in Germany, Berichte Uber Landwirtschaft [online] 90(3): 467-489 [cited 15 March 2014]. Available from Internet: http://bazy.pb.edu.pl:2749/full_record.do?product=UA\&search_ mode $=$ GeneralSearch\&qid $=2 \&$ SID $=$ T24ooM1DI5hH9UJfiVb\&page

Hertz, T. 2009. The effect of nonfarm income on investment in Bulgarian family farming, Agricultural Economics 40(2): 161-176. http://dx.doi.org/10.1111/j.1574-0862.2009.00367.x 
Hrabalová, A.; Zander, K. 2006. Organic beef farming in the Czech Republic: structure, development and economic performance, Agricultural Economics [online] 52(2): 89-100 [cited 12 May 2012 ]. Available from Internet: http://www.agriculturejournals.cz/publicFiles/58000.pdf

Hughner, R. S.; McDonagh, P.; Prothero, A.; Shultz, C. J.; Stantion, J. 2007. Who are organic food consumer? A compilation and review of why people purchase organic food, Journal of Consumer Behaviour 6(2-3): 94-110. http://dx.doi.org/10.1002/cb.210

Jánský, J.; Živělová, I. 2006. Subsidies for the organic agriculture, Agricultural Economics [online] 53(9): 393-402 [cited 12 May 2012]. Available from Internet: http://www.agriculturejournals.cz/publicFiles/00384.pdf

Kłos, L. 2011. Rolnictwo ekologiczne jako element trwałego i zrównoważonego rolnictwa [Organic farming as an element of stable and sustainable farming], Ekonomia i Środowisko 1(39): 120-133.

Koloszko-Chomentowska, Z. 2003. Wyposażenie w środki trwałe jako element konkurencyjności gospodarstw rolniczych [Equipment in fixed assets as part of farms competitiveness], Prace Naukowe Uniwersytetu Ekonomicznego we Wrocławiu 983(1): 390-395.

Koloszko-Chomentowska, Z. 2011. Gospodarstwa ekologiczne w zrównoważonym rozwoju rolnictwa na przykładzie woj. Podlaskiego [Ecological farms in sustainable development of farming using as an example Podlaskie voivodship], Ekonomia i Środowisko 1(39): 134-142.

Koloszko-Chomentowska, Z. 2012. Farms development in the context of sustainable development, Management Theory and Studies for Rural Business and Infrastructure Development 2(31): 62-67. Lithuanian Institute of Agrarian Economics, Vilnius, Aleksandras Stulginskis University, Kaunas.

Kozłowski, S. 1996. Zrównoważony rozwój - wyzwanie przyszłości [Sustainable development - the challenge of the future], Człowiek i Przyroda 15: 14-17.

Kurlavicius, A. 2009. Sustainable agricultural development: knowledge - based decision support, Technological and Economic Development of Economy 15(2): 294-309. http://dx.doi.org/10.3846/1392-8619.2009.15.294-309

Lansink, A. O.; Pietola, K.; Backman, S. 2002. Efficiency and productivity of conventional and organic farms in Finland 1994-1997, European Review of Agricultural Economics 29(1): 51-65. http://dx.doi.org/10.1093/erae/29.1.51

Lawn, P. A. 2003. A theoretical foundation to support the Index of Sustainable Economic Welfare (ISEW), Genuine Progress Indicator (GPI) and other related indexes, Ecological Economics 44: 105-118. http://dx.doi.org/10.1016/S0921-8009(02)00258-6

Lichtfouse, E.; Navarrete, M.; Debaeke, Ph.; Souchere, V.; Alberola, C.; Menassien, J. 2009. Agronomy for sustainable agriculture, Agronomy for Sustainable Development 29(1): 1-6. http://dx.doi.org/10.1051/agro:2008054

Liu, Y. 2010. Establishing modern concept of wealth: promoting Chinese social sustainable development, Journal of Sustainable Development 3(4): 248-251. http://dx.doi.org/10.5539/jsd.v3n4p248

Łapińska, J. 2009. Rozwój rolnictwa ekologicznego w Republice Czeskiej [Development of organic agriculture in the Czech Republic], Roczniki Naukowe Stowarzyszenia Ekonomistów Rolnictwa i Agrobiznesu 11(2): 142-146.

Łojewski, S.; Adamczyk-Łojewska, G.; Bujarkiewicz, A. 2000. Determinants of sustainable development of rural areas in Poland - results of an economic-spatial analysis, Journal of Water and Land Development 4: 5-31.

Majewski, E. 2008. Trwały rozwój i trwałe rolnictwo [Sustainable development and sustainable agriculture]. Warszawa: Wyd. SGGW. 199 p.

Musshoff, O.; Hirschauer, N. 2008. Adoption of organic farming in Germany and Austria: an integrative dynamic investment perspective, Agricultural Economics 39(1): 135-145.

http://dx.doi.org/10.1111/j.1574-0862.2008.00321.x 
Nachtman, G. 2009. Wpływ dopłat na dochody gospodarstw ekologicznych o różnej wielkości obszarowej w $2007 \mathrm{r}$. [The influence of additional payments on earnings of organic farms with different area size in 2007], Zagadnienia Doradztwa Rolniczego 3: 83-97.

Nachtman, G. 2010. Ocena dochodów gospodarstw ekologicznych na tle gospodarstw konwencjonalnych w 2008 r. w świetle danych Polskiego FADN [The estimation of incoming of organic farms in 2008 on the basic of Polish FADN], Zagadnienia Doradztwa Rolniczego 3: 30-43.

Nachtman, G. 2011. Zmiany sytuacji ekonomicznej grupy gospodarstw ekologicznych w latach 2005-2008 na podstawie Polskiego FADN [Changes in the economic standing of organic holdings in the years 2005-2008 based on the Polish FADN], Zagadnienia Ekonomiki Rolnej 3(328): 162-177.

O'Donovan, P.; McCarthy, M. 2002. Irish consumer preference for organic meat, British Food Journal 104(3/4/5): 353-370. http://dx.doi.org/10.1108/00070700210425778

Offerman, F.; Nieberg, K.; Zander, K. 2009. Dependency of organic farms on direct payments in selected EU member states: today and tomorrow, Food Policy 34(3): 273-279. http://dx.doi.org/10.1016/j.foodpol.2009.03.002

O'Hara, J. K.; Parsons, R. L. 2013. The economic value of organic dairy farms in Vermont and Minnesota, Journal of Dairy Science 96(9): 6117-6126. http://dx.doi.org/10.3168/jds.2013-6662

Patil, S.; Redsma, P.; Shah, P.; Purushothaman, S.; Wolf, J. 2014. Comparing conventional and organic agriculture in Karnataka, India: where and when can organic farming be sustainable?, Land Use Policy 37: 40-51. http://dx.doi.org/10.1016/j.landusepol.2012.01.006

Pfeiffer, L.; Lopez-Feldman, A.; Taylor, E. 2009. Is off-farm income reforming the farm? Evidence from Mexico, Agricultural Economics 40(2): 125-138. http://dx.doi.org/10.1111/j.1574-0862.2009.00365.x

Raport o stanie rolnictwa ekologicznego w Polsce w latach 2009-2010 [Report on the condition of organic farming in Poland in 2009-2010] . 2011. Warsaw: GIHARS.

Raport o stanie rolnictwa ekologicznego w Polsce w latach 2011-2012 [Report on the condition of organic farming in Poland in 2011-2012]. 2013. Warsaw: GIHARS.

Redlichova, R. 2007. Economic evaluation of organic farms, Roczniki Naukowe Stowarzyszenia Ekonomistów Rolnictwa i Agrobiznesu 9(1): 406-410.

Statistical yearbook of voivodeship in Poland. 2013. Warsaw: Central Statistical Office of Poland. 532 p.

Stuczyński, T.; Budzyńska, K.; Gawrysiak, L.; Zalewski, A. 2000. Waloryzacja rolniczej przestrzeni produkcyjnej Polski [Valorization of the agricultural production space in Poland]. Selected paper. Instytut Uprawy Nawożenia i Gleboznawstwa- Państwowy Instytut Badawczy, Puławy 12: 4-17.

Ustawa z dnia 25 czerwca 2009 r. o rolnictwie ekologicznym [The Act of 25 June 2009. On organic farming], Dziennik Ustaw Nr. 116, 975 [Journal of Laws No. 116, item 975].

Wysokińska, Z. 2009. The international environmental goods and services market: an opportunity for Poland, Polish Journal of Environmental Studies 18(5): 941-948.

Zámková, M.; Blašková,V. 2013. The differences in the marketability of organic products in Greece and the Czech Republic, Agricultural Economics [online] 59(5): 219-226 [cited 15 March 2014]. Available from Internet: http://www.agriculturejournals.cz/publicFiles/92904.pdf

Zander, K.; Nieberg, H.; Offermann, F. 2008. Financial relevance of organic farming payments for Western and Eastern European organic farms, Renewable Agriculture and Food Systems 23(1): 53-61. http://dx.doi.org/10.1017/S1742170507002050

Zofia KOLOSZKO-CHOMENTOWSKA. Doctor, Assistant Professor at the Department of Finance and Accountancy, Bialystok University of Technology. Member of the Scientific Council of the National Association of Farmers and Agricultural Organizations. Author and co-author of more than 100 scientific articles. Research interests: agricultural finance, economic and organization of agricultural holdings, investment in agriculture, organic farming, sustainable development of agriculture and rural areas. 